\title{
Visibilidade na Mídia e Campo Político no Brasil ${ }^{*}$
}

\author{
Luis Felipe Miguel $^{1}$ \\ Flávia Biroli ${ }^{2}$ \\ ${ }^{1}$ Professor do Instituto de Ciência Política da Universidade de Brasília (UnB). \\ E-mail: lfelipemiguel@uol.com.br \\ ${ }^{2}$ Professora do Instituto de Ciência Política da Universidade de Brasília (UnB). \\ E-mail: fbiroli@terra.com.br
}

$\mathrm{O}$

s estudos sobre a relação entre os meios de comunicação de massa e a política tendem a se concentrar em seu impacto sobre as campanhas eleitorais. Por um lado, o advento dos meios de massa, em especial do rádio e da televisão, alterou as formas de contato entre candidatos e eleitores, reduzindo a centralidade dos partidos, exigindo novas formas de apresentação pessoal e novos recursos oratórios e conferindo proeminência a um novo tipo de consultor político (o "marqueteiro"). Por outro lado, as representações do mundo social veiculadas pela mídia afetam as preferências dos cidadãos e, assim, influenciam os resultados eleitorais. A maior parte da literatura sobre mídia e política, tanto no exterior como no Brasil, gira em torno dessas questões ${ }^{1}$.

No entanto, a influência da mídia na ação política vai muito além dos processos eleitorais. Os meios de comunicação de massa ecoam nos discursos parlamentares, têm impacto na formação da agenda legislativa, fazem as vezes de fórum de discussão para as elites políticas. E - o que interessa em especial ao presente artigo - a visibilidade midiática é um componente importante na produção do capital político. Mais ain-

\footnotetext{
* Este artigo incorpora parte dos resultados da pesquisa Determinantes de Gênero, Visibilidade Midiática e Carreira Política no Brasil, apoiada pelo Conselho Nacional de Desenvolvimento Científico e Tecnológico (CNPq), com recursos dos editais no 45/ 2005 e no 61 / 2005 e de bolsas de Produtividade em Pesquisa; e pela Fundação de Apoio à Pesquisa (FAP) do Distrito Federal, com recursos do edital no 5/2008.
}

DADOS - Revista de Ciências Sociais, Rio de Janeiro, vol. 53, n-3, 2010, pp. 695 a 735. 
da, as formas dessa visibilidade contribuem para abrir ou fechar oportunidades e, desse modo, orientam as carreiras políticas. Possuem impacto sobre a compreensão que os cidadãos comuns têm da política e do comportamento de atores específicos e fazem parte, também, das relações e formas de valorização dentro de partidos políticos e em diferentes espaços e dimensões em que essas carreiras se constroem. Por isso, a gestão da imagem pública, que é sobretudo a gestão da visibilidade pessoal na mídia, é uma preocupação central e permanente dos atores políticos e não se limita aos períodos de competição eleitoral.

Entendendo-se a política como um campo hierarquizado, no sentido de Pierre Bourdieu (1986), é insuficiente postular, como fazem muitos estudos sobre carreira política, a "ambição progressiva" (Schlesinger, 1966; Rohde, 1979) daqueles que desejam exercer o poder. A luta pela acumulação de capital político, isto é, pelo acesso às posições centrais no campo, não se limita à conquista de cargos eletivos mais elevados. Dois integrantes de uma mesma casa legislativa podem possuir capacidades de influência muito diferenciadas, isto é, suas posições no campo político são distantes entre si. Uma derrota eleitoral numa disputa importante pode cacifar a posição de líder da oposição, com maior peso nas negociações políticas, mais do que a conquista de um cargo de menor expressão. Assim, os agentes no campo político lutam pela ampliação de seu "capital" - entendido como o reconhecimento, pelos pares, de sua relevância naquele universo -, o que inclui a obtenção de cargos, mas não se confunde com ela.

O representante se afirma como tal por se constituir em porta-voz de determinados setores sociais, reconhecido pelos seus representados e pelos outros agentes políticos - o que também não se confunde necessariamente com o exercício de um mandato formal. A concorrência entre os agentes no campo político é uma concorrência pelo direito de falar em nome de outros. Um componente importante para a obtenção desse direito é a visibilidade social. Nas sociedades contemporâneas, a mídia é o principal espaço de produção dessa visibilidade. O fato de que as ações dos políticos sejam potencialmente visíveis age sobre a política mesmo quando o noticiário atinge um público restrito ou tem pouco impacto sobre as percepções do público. Por isso, é possível dizer que a visibilidade é um elemento importante por si mesmo (Schudson, 1995:24-25), definindo uma lógica que precede suas peculiaridades em contextos específicos. 
É a partir daqui que se pode afirmar a relevância política dos meios de comunicação de massa. Seu diferencial, entre outras instituições que têm impacto para a construção do mundo simbólico, é conferir uma espécie de "certificado de importância legítima" aos temas e personagens que torna visíveis (id., ibid.:33). Assim, gerir a difusão da própria imagem na mídia se torna uma das preocupações permanentes dos agentes políticos, que se esforçam tanto para garantir visibilidade para si próprios - sem a qual suas pretensões à liderança se esfumaçam quanto para reduzir e, se possível, suprimir os aspectos negativos nela contidos (Miguel, 2002).

A relação entre a visibilidade na mídia e a produção do capital político - entendido como a incorporação, pelos agentes, dos elementos de valorização e distinção reconhecidos, legitimados e naturalizados, em uma dada estrutura do campo - no Brasil é o objeto deste artigo. Os meios de comunicação são percebidos ao mesmo tempo como fonte e índice de capital político. A partir de um conjunto de normas e valores que definem o que é noticiável e quem compõe a notícia, os meios de comunicação (especificamente o jornalismo) conferem distinção na medida em que tornam visíveis determinadas personagens. Ao mesmo tempo, a visibilidade é a "constatação", pelo jornalismo, de distinções e competências definidas com base em normas, valores e hierarquias que regem o campo da política e que os meios de comunicação absorvem $^{2}$.

A homogeneidade da cobertura nos veículos de grande circulação está relacionada ao compartilhamento, pelos jornalistas, de compreensões comuns sobre o que é a política, em que espaços se dá e quais são os atores relevantes. $\mathrm{O}$ jornalismo apresenta padrões rotineiros no contato com os atores políticos. Estes, por sua vez, assimilam a lógica que colabora para a distinção de temas e personagens no cotidiano da produção jornalística. A colaboração entre jornalistas e fontes tem uma faceta menos explícita, a do acordo tácito quanto aos valores e aos limites da política. Os atores políticos antecipam o que é capaz de atrair os jornalistas, enquanto estes últimos antecipam as reações das suas fontes às histórias noticiadas, em uma dinâmica que ressalta a colaboração entre o jornalismo e a política e favorece determinadas abordagens (Cook, 2005:91).

A relação entre a visibilidade na mídia e a posição ocupada no campo político apresenta características específicas, se considerarmos o sexo 
das personagens. Nesse caso, a relação entre a presença escassa de mulheres na política e sua pouca visibilidade na mídia se liga à vinculação delas a temáticas que definem os limites para sua atuação e competência. É um exemplo de como a presença nos meios de comunicação apresenta matizes diferentes e não é, em si, um ganho na luta por posições políticas. A política veiculada no noticiário é composta de temas e personagens que são posicionados de modo a confirmar ou a deslocar as hierarquias ativas no campo político. Isso está relacionado ao fato de que existe uma interface entre as hierarquias existentes em outros campos e a presença nos meios de comunicação, isto é, à própria existência ampliada que a mídia permite àqueles que atuam em campos sociais diversos. Mas está relacionado às hierarquias presentes no noticiário, que organizam as posições daqueles que conquistam essa visibilidade. As competências e estereótipos - de gênero, mas não só - aos quais as personagens são vinculadas têm um papel na construção e consolidação de suas carreiras.

Com base nessas constatações, o artigo analisa o resultado de uma ampla pesquisa sobre as representações da política nos meios de comunicação de massa. A seleção dos temas e personagens que estão presentes no noticiário, com a observação, em particular, das diferenças entre homens e mulheres, foi considerada um aspecto importante das formas assumidas pela política na mídia brasileira. Por um período de quase dez meses, distribuídos ao longo de um ano e meio, foi realizado o acompanhamento sistemático do noticiário de três telejornais diários e de três revistas semanais de informação. A primeira seção do artigo explica o desenho de pesquisa. A segunda mostra o perfil do noticiário que emerge dos dados, enfatizando continuidades e diferenças entre períodos e entre veículos. A terceira indica quem são as personagens do noticiário político. A quarta analisa quem tem acesso à voz, nos telejornais e nas revistas de informação, e de que formas. A quinta seção, enfim, foca as diferenças, nesse noticiário, na presença de mulheres e de homens. Uma breve conclusão discute qual o significado dos dados para o entendimento do que é a política - quem a faz, quais seus limites - no Brasil.

\section{A PESQUISA E SEU MÉTODO}

Para a pesquisa, foi realizado o acompanhamento de três telejornais noturnos de redes nacionais e de três revistas semanais de informação durante três períodos de três meses cada, entre o primeiro semestre de 
2006 e o primeiro semestre de 2007. A opção por períodos contínuos, no lugar da adoção de ferramentas de amostragem, como a geração de "semanas compostas" ou "meses compostos", permitiu o acompanhamento de determinados tópicos e da construção discursiva associada a elas. $\mathrm{O}$ fato de esses períodos serem três momentos diferentes - um período "pré-eleitoral" no começo de 2006, as eleições no fim de 2006 e um período "pós-eleitoral" em 2007, quando os eleitos já haviam sido empossados - contribuiu para equilibrar a amostra, compensando o peso que um evento específico, como a própria disputa eleitoral, tem na cobertura da mídia.

A televisão é a mídia dominante no Brasil, país que combina altos índices de penetração dos meios eletrônicos com fraca escolarização, que compromete tanto a circulação da mídia impressa quanto a utilização da internet. Dados de 2007 informam que 97,1\% dos lares possuem ao menos um televisor. E a televisão, sozinha, recebe mais da metade da verba publicitária do país. Ainda que os chamados "formadores de opinião", em geral, e a elite política, em particular, tendam a privilegiar outros meios informativos, uma pesquisa entre deputados federais indicou que $62,2 \%$ deles assistem a telejornais todos os dias - e outros 23,6\% assistem-nos algumas vezes por semana (FSB Comunicações, 2008:16). A centralidade da televisão é confirmada pela circulação restrita da mídia impressa. Em 2008, a circulação diária média dos principais jornais era de 4.351 .000 exemplares, o que corresponde a aproximadamente $2 \%$ da população (Instituto Verificador de Circulação, 2009).

Os telejornais incluídos na pesquisa foram o Jornal Nacional, o Jornal da Band e o SBT Brasil, todos transmitidos diariamente (exceto aos domingos), na faixa de programação noturna de maior audiência, o chamado "horário nobre". O Jornal Nacional é o principal produto informativo do maior conglomerado de mídia do Brasil, a Rede Globo de Televisão, e foi o primeiro programa a ser exibido em rede nacional. Se, no período da pesquisa, não estava mais no auge - como nos anos 1970, quando ultrapassava os 70 pontos de audiência -, ainda superava a média de 30 pontos, o que corresponde a mais de 2,5 milhões de espectadores diários só na grande São Paulo. Trata-se, ainda, do telejornal mais assistido pela própria elite política, apontado como o preferido por 60,6\% dos deputados federais (FSB Comunicações, 2008:17). 
O Jornal da Band, da Rede Bandeirantes, é o mais tradicional concorrente do Jornal Nacional, de uma emissora menor, mas com tradição em telejornalismo, ao passo que o SBT Brasil, do Sistema Brasileiro de Televisão, era um investimento novo na época. Na errática condução da emissora por seu proprietário, Silvio Santos, representava uma tentativa de obtenção de respeitabilidade, conduzida por uma profissional que havia sido uma das estrelas do jornalismo da Rede Globo, Ana Paula Padrão. Ambos os telejornais tinham, à época, audiência média em torno de 6-7 pontos.

As revistas analisadas pela pesquisa foram Veja, Época e CartaCapital. A primeira, da Editora Abril, circula desde 1968 e é a principal revista de informação brasileira, com tiragem declarada superior a um milhão de exemplares semanais. Ela se caracteriza pelo tom fortemente opinativo de suas matérias e uma pouco disfarçada inclinação por posições políticas à direita, com histórica aversão ao Partido dos Trabalhadores (PT), hoje no poder. A revista Época, surgida em 1998 como adaptação brasileira da tradicional publicação alemã Focus, pertence à Editora Globo - braço das Organizações Globo na mídia impressa - e tem tiragem média semanal de cerca de 400 mil exemplares. Já a CartaCapital é um projeto do jornalista Mino Carta, que foi criador de diversos veículos da imprensa brasileira, dentre eles a própria Veja.Surgida em 1994, com periodicidade mensal, tornou-se quinzenal em 1996 e semanal em 2001. Com tiragem em torno de 65 mil exemplares por semana, busca atingir um público de elite, combinando uma cobertura política que se quer mais aprofundada com um extenso noticiário sobre o mercado financeiro. Diferencia-se também por uma postura vista como mais à esquerda e pela simpatia em relação ao governo Lula.

As revistas semanais não têm público tão amplo e diversificado quanto os telejornais, mas possuem impacto junto aos chamados "formadores de opinião" e um papel importante no agendamento recíproco entre os veículos. Um exemplo conhecido do papel das revistas no agendamento de campanhas e na produção da visibilidade (positiva ou negativa) dos atores é o da promoção de Fernando Collor de Mello nos meses prévios à campanha de 1989, seguida, mais tarde, das denúncias de corrupção, que culminaram no seu impeachment. Depois disso, as revistas também tiveram um papel destacado na circulação das denúncias relacionadas à chamada "crise do mensalão". Mas sua importância, ao produzir uma "síntese" semanal do noticiário político, voltada para segmentos específicos da população, não se restringe aos períodos 
eleitorais ou a eventos específicos. Tendem a adotar um estilo mais "opinativo" e a intenção, nada disfarçada, de orientar a apreciação de seus leitores sobre o mundo. Entre os deputados federais, 87,8\% afirmam ler revistas todas as semanas, com ampla vantagem para Veja (78\%), seguida de IstoÉ $(52,8 \%)$, Época $(40,2 \%)$ e CartaCapital $(25,2 \%)$ (FSB Comunicações, 2008:22-3).

O acompanhamento foi diário, no caso dos telejornais, e semanal, no das revistas ${ }^{3}$. Foram observadas 12 semanas, entre 6 de março e 27 de maio de 2006; 15 semanas, entre 10 de julho e 28 de outubro de 2006; e mais 12 semanas, no primeiro semestre de 2007 - entre 5 de março e 26 de maio para os telejornais e de janeiro a março para as revistas. O período eleitoral é maior, de maneira a abarcar do final da Copa do Mundo até a realização do segundo turno das eleições, gerando dados comparáveis com pesquisas realizadas sobre a cobertura jornalística em 1998 e 2002 (Miguel, 1999; 2003; 2004). Problemas técnicos na gravação comprometeram uma parcela significativa da amostra dos telejornais - 37,5\% das edições do período pré-eleitoral, $19,9 \%$ do período eleitoral e $11,1 \%$ do período pós-eleitoral. Ao todo, foram incluídas $77,8 \%$ das edições previstas do Jornal Nacional, 76,9\% do Jornal da Band e $78,6 \%$ do SBT Brasil. Uma vez que as falhas ocorreram de maneira aleatória, consideramos que elas não enviesaram os resultados. A coleção das revistas estava completa.

Uma ficha de acompanhamento foi preenchida para cada matéria ${ }^{4}$, de maneira a identificar as áreas temáticas predominantes nos telejornais e nas revistas. Em seguida, as "personagens" das matérias de política foram identificadas - sendo consideradas "personagens" as pessoas que, não pertencendo à equipe jornalística, apareceram no noticiário, seja na qualidade de entrevistadas, de fontes ou mesmo apenas citadas por algum repórter, colunista, apresentador ou por outra personagem.

Foram determinadas, após pré-teste, 26 categorias temáticas, 11 das quais se vinculavam à área de "política brasileira":

- Cidades (Brasil) - inclui matérias sobre trânsito, transporte coletivo, direito do consumidor, greves em serviços públicos (exceto educação e saúde, encaixadas em categorias próprias) etc.

- Ciência/tecnologia - novidades científicas, médicas e tecnológicas;

- Desastres - catástrofes naturais, acidentes de trânsito e ferroviários, desastres aéreos etc. 
- Ecologia/meio ambiente - espécies ameaçadas, áreas de preservação, aquecimento global etc.

- Economia brasileira - inflação, desemprego, câmbio, dívida pública, balança comercial e de pagamentos, reajustes salariais etc. (exceto decisões de política econômica, que foram consideradas "política brasileira");

- Educação - vagas no ensino público, vestibular, ação afirmativa e outras formas de acesso ao ensino superior, distribuição de material didático, experiências inovadoras na educação no Brasil, greves de professores etc.;

- Esportes;

- Fait-divers - curiosidades, anúncios de programas da própria emissora, fofocas sobre celebridades, eventos da indústria cultural, "mundo animal" etc.;

- Internacional - política externa brasileira, relações exteriores, política interna de outros países etc.;

- Lições de vida-abordagem "edificante", mostrando como indivíduos e/ou grupos superam suas dificuldades;

- Polícia - crimes, busca de criminosos, revoltas de presidiários etc.; não inclui políticas públicas de segurança, que possui categoria própria;

- Política brasileira: ações do Poder Executivo Federal - incluindo o lançamento de programas, o preenchimento de cargos, a liberação de recursos;

- Política brasileira: propostas legislativas e ações no Congresso - ações do e no Congresso; inclui o debate e tramitação de toda e qualquer proposta legislativa, inclusive quando de iniciativa do Poder Executivo;

- Política brasileira: Judiciário - decisões judiciais, em especial das cortes superiores, com repercussão política; inclui também ações de órgãos com ação de tipo judicial que pertencem ao Poder Legislativo (Tribunal de Contas) ou ao Poder Executivo (Ministério Público);

- Política brasileira: escândalos - denúncias e investigações de atos ilícitos, improbidades e desvios de conduta em geral envolvendo governantes, parlamentares, líderes partidários e ocupantes dos primeiros escalões das administrações municipais, estaduais e federal;

- Política brasileira: eleições (resultado de pesquisas) - toda e qualquer divulgação de sondagens de intenções de voto, bem como de resultados eleitorais; 
- Política brasileira: eleições (curiosidades/serviço) - informações aos eleitores (como usar a urna, como justificar ausência etc.) e curiosidades à margem do processo eleitoral (trabalho dos Tribunais Regionais Eleitorais (TREs) nas fronteiras do país, eleitores idosos ou jovens etc.);

- Política brasileira: eleições (debate eleitoral) - falas dos candidatos e de outros líderes políticos, programas de governo, eventos de campanha (passeatas, comícios etc.), denúncias contra candidatos;

- Política brasileira: vida partidária - conflitos internos de partidos, escolha de líderes etc.;

- Política brasileira: movimentos sociais/sociedade civil - ação de movimentos sociais ou de entidades da sociedade civil;

- Política brasileira: história/curiosidades - lembrança de episódios passados da política nacional, motivadas por efemérides (como os cinquenta anos do suicídio de Vargas) ou falecimentos (por exemplo, a biografia de Leonel Brizola); curiosidades da política nacional;

- Política brasileira: outros/mix - reportagens de política brasileira que mesclam várias das categorias anteriores, sem que seja possível indicar uma predominância;

- Previsão do tempo;

- Saúde pública - epidemias, saneamento, controle de medicamentos, rede hospitalar, greves de profissionais da saúde etc.;

- Segurança pública - políticas de segurança pública;

- Outros - categoria residual para matérias que não se encaixam em nenhuma das anteriores; no caso das revistas, inclui cartas dos leitores, seções de "frases da semana" e de notas variadas etc.

Ao todo, foram assistidas e fichadas 241 horas, 23 minutos e 43 segundos de telejornais. Não foram incluídas nem as chamadas iniciais (a "escalada", em que os apresentadores anunciam as principais notícias do dia), nem as chamadas ao final de cada bloco. A participação dos três noticiários no corpus foi equilibrada, com ligeira predominância do Jornal da Band (35,4\% do tempo), seguido de SBT Brasil (32,5\%) e Jornal Nacional $(32,1 \%)$.

Quanto às revistas, foram lidas e fichadas 7.751 páginas, excluídas as capas e os anúncios. Época (37\% das páginas) e Veja $(36,1 \%)$ contribuíram com parcelas semelhantes do corpus e CartaCapital com um pouco menos $(26,9 \%)$, o que reflete seu perfil de publicação mais enxuta. 


\section{A HOMOGENEIDADE DA COBERTURA}

Agrupadas, as onze categorias de "política brasileira" ficam com a maior fatia do noticiário da televisão, totalizando $24,2 \%$ do tempo dos telejornais pesquisados. Não causa surpresa o fato de que esse percentual seja maior no período eleitoral, quando alcança 32,9\%; e a diferença entre os outros dois períodos se explica pelo fato de que, no primeiro semestre de 2006, o noticiário ainda era alimentado pelos desdobramentos do escândalo do chamado "mensalão" (o pretenso pagamento de propinas para deputados, com dinheiro desviado de órgãos públicos, a fim de que apoiassem o governo, denunciado em maio de 2005). Assim, o noticiário político ocupa $27,6 \%$ do tempo dos telejornais no período pré-eleitoral, contra meros $14,5 \%$ no período pós-eleitoral.

De fato, a subcategoria "escândalos" responde pela maior fatia das reportagens de política na televisão, 30,4\% - mais até do que o conjunto das três subcategorias vinculadas ao processo eleitoral, que somam $24,5 \%$ das matérias de política. E é no período pré-eleitoral que os escândalos merecem atenção, concentrando $37,6 \%$ do noticiário político. No período pós-eleitoral, ao contrário, talvez por conta da atenção concedida ao novo mandato presidencial, cresce a presença de matérias sobre ações do Poder Executivo Federal.

O perfil de ocupação do espaço das revistas é diferenciado, com predomínio da categoria fait-divers, que ocupou $31,2 \%$ das suas páginas. As categorias de política brasileira, agrupadas, vêm em seguida, com $20,1 \%$ do espaço. Mas a curva é similar à dos telejornais, como mostra o Gráfico 1. Política brasileira ocupa 21,3\% das páginas das revistas no período pré-eleitoral, quase metade delas relacionadas a escândalos, subindo para $27,5 \%$ no período eleitoral e caindo para $10,9 \%$ no período pós-eleitoral. No corpus total, a subcategoria "escândalos" é, de longe, a mais importante, ocupando $29,5 \%$ das páginas do noticiário político das revistas. Segue-se a subcategoria "outros/mix", com 18,1\% do espaço dedicado à política brasileira, que reflete uma prática comum aos três semanários analisados: produzir uma grande matéria de síntese dos fatos políticos, em que ações do governo, manobras no Congresso, estratégias eleitorais e escândalos podem estar mesclados.

Os dados também confirmam elementos constantes do jornalismo brasileiro dos últimos anos, observados em pesquisas anteriores, como a fraca atenção concedida ao noticiário internacional, que fica com $10 \%-12 \%$ do tempo dos telejornais e $8 \%-11 \%$ do espaço das revistas, 
Gráfico 1

Proporção do tempo/espaço dedicado ao noticiário político, em telejornais e revistas semanais de informação

(2006-2007)

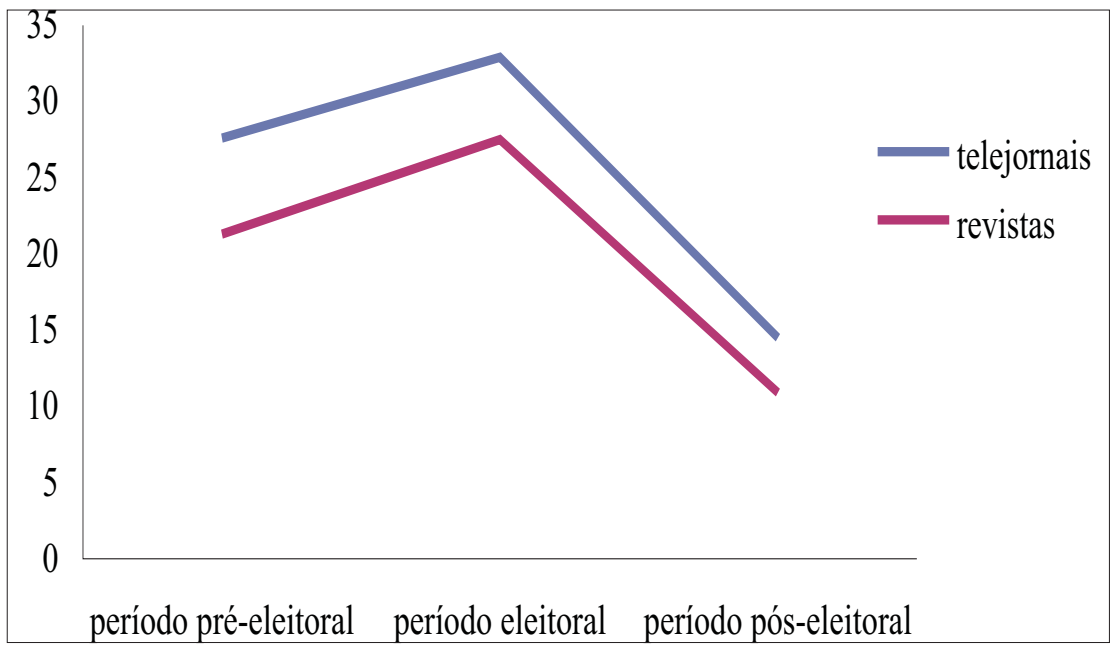

nos três períodos (e se concentra nos Estados Unidos e no Oriente Médio). A revista CartaCapital, com média de $15 \%$ de suas páginas voltadas ao noticiário internacional e maior diversidade nessa cobertura, foge ao padrão e, portanto, reafirma seu perfil mais "elitizado" ou "intelectualizado".

Já o noticiário de variedades, que além da categoria fait-divers propriamente dita inclui desastres, esportes, lições de vida e polícia, ocupou em média $34,2 \%$ do tempo dos telejornais - um pouco abaixo disso no período eleitoral, um pouco acima nos outros dois. São números comparáveis aos do Jornal Nacional em 2002 e bem diferentes daqueles apresentados pelo noticiário da Rede Globo em 1998, quando as variedades abocanhavam mais de 50\% do tempo (Miguel, 2003:298) ${ }^{5}$. Para as revistas, a média foi de $36,9 \%$ do espaço dedicado a variedades, com a CartaCapital apresentando uma proporção um pouco inferior à de suas concorrentes $(32,9 \%)$.

Separados os dados em função de cada telejornal analisado, observa-se que as diferenças de perfil entre eles, embora presentes, não são de grande monta. O Jornal da Band dedica mais tempo ao noticiário das cidades e menos ao internacional do que seus concorrentes. O SBT Brasil concentra-se mais no fait-divers e no noticiário policial, e menos em esportes. As diferenças giram em torno de 3 a 5 pontos percentuais. 
Apenas na cobertura da política brasileira se registra uma disparidade maior, alcançando $31,2 \%$ do tempo do Jornal Nacional contra 20,8\% do Jornal da Band e 20,9\% do SBT Brasil. O Jornal Nacional dedica uma parcela maior de seu noticiário à política brasileira em todos os três períodos, chegando a $41,5 \%$ no período eleitoral. E todos os telejornais diminuem significativamente o tempo destinado ao assunto no período pós-eleitoral.

Focando apenas o noticiário político, as dessemelhanças entre os três telejornais permanecem sutis. O SBT Brasil dá um pouco mais de destaque a ações do Poder Executivo Federal, que ocupam 16,9\% de seu noticiário político, contra cerca de $13 \%$ dos outros, e também à vida partidária, $\operatorname{com} 8,1 \%$, mais que o dobro dos outros. Já o Jornal Nacional cobre um pouco menos o Poder Legislativo, totalizando 6,5\% do seu tempo de noticiário político, ao passo que seus concorrentes ficam entre $8 \%-10 \%$. Mas é ao diferenciar os três períodos examinados como faz a Tabela 1, que a análise se torna mais interessante.

Começando nossa análise pelo Jornal Nacional, percebemos a brutal queda da atenção concedida às ações do Poder Executivo Federal durante as eleições. Ocupando mais de um quarto do noticiário político do telejornal da Rede Globo nos outros períodos, a categoria praticamente some entre julho e outubro de 2007, ficando com menos de $1 \%$ do tempo. Nos outros telejornais, a redução do tempo destinado ao Poder Executivo Federal no período das eleições também é grande, indicando que se trata de uma mudança de prioridades de pauta - e o fato de que o candidato Luiz Inácio Lula da Silva tendia a se sobrepor ao presidente Luiz Inácio Lula da Silva. No caso do Jornal Nacional, porém, o desaparecimento do noticiário relativo às ações do Executivo Federal sugere que, além disso, houve uma postura deliberada. Se foi assim, repete-se o quadro de 2002, quando, buscando repelir a imagem de manipuladora da opinião pública, fruto de sua ação em eleições anteriores, a Globo optou por um equilíbrio estrito no tempo dedicado a cada um dos principais candidatos (Miguel, 2003). Naquele ano, contudo, o presidente da República não era candidato à reeleição, situação que, presente em 2006, impôs novos problemas aos órgãos de imprensa na busca de imparcialidade ostensiva.

Há outro dado que deve ser levado em conta. No período eleitoral, a concentração do noticiário político nas eleições - cujas três categorias somam entre $41,5 \%$ e $48,9 \%$, nos três telejornais - pressiona para baixo 
Visibilidade na Mídia e Campo Político no Brasil

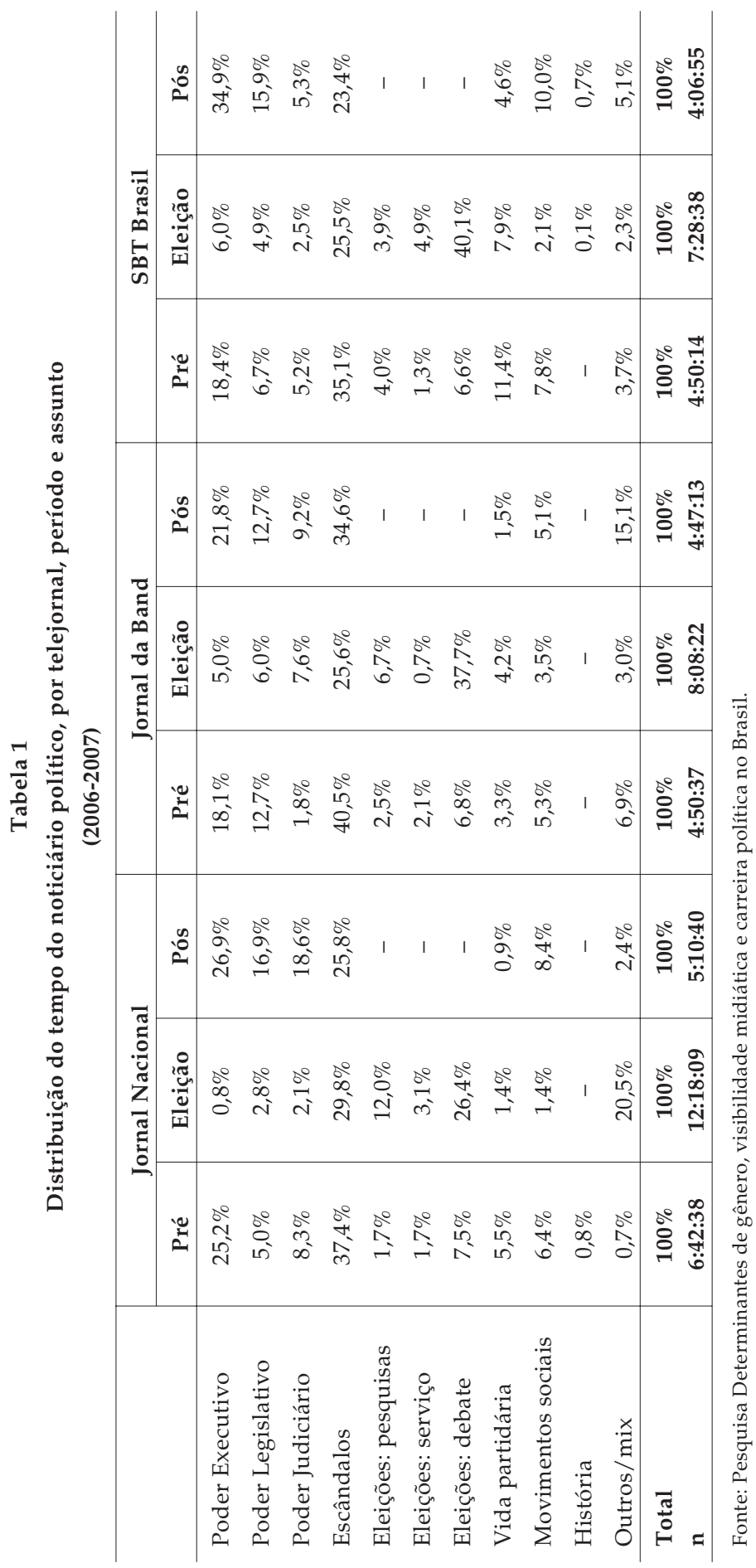


os percentuais de todas as outras categorias, não apenas das ações do Executivo Federal. A principal exceção é a categoria "mix", para o Jornal Nacional, que apresenta notável acréscimo no período, passando de menos de $1 \%$ para mais de $20 \%$. Esses números refletem a opção editorial do telenoticiário da Rede Globo, que mesclou a cobertura da campanha com a cobertura do governo federal, tratando de ambos os assuntos nas mesmas matérias. Todavia, não é surpreendente a maior presença do resultado de sondagens de intenção de voto no Jornal Nacional, uma vez que a Rede Globo, maior e com mais recursos, contratava institutos de pesquisa que serviam não só aos telenoticiários, mas a todos os veículos de comunicação do conglomerado (notadamente a rádio all-news CBN, o canal de notícias por assinatura GloboNews, o jornal O Globo, a revista Época e o portal de internet G1).

O "escândalo", entendido como denúncias de atos ilícitos praticados por funcionários públicos e as investigações delas resultantes, é um dos motores do noticiário político. Se, por um lado, a ênfase na denúncia e no escândalo custa aos jornalistas a acusação, frequente, de contribuir para o desgaste das instituições republicanas ${ }^{6}$, por outro, ela seria a demonstração de que estão sendo cumpridas as responsabilidades de "quarto poder" ou de watchdog, a quem cabe zelar para que as leis e a moralidade pública sejam respeitadas. Num mundo "onde poder e reputação andam de mãos dadas", o escândalo é importante porque "afeta as fontes concretas do poder" (Thompson, 2002:23). Os três telejornais dão destaque aos escândalos, que em geral ocupam entre um quarto e dois quintos do tempo do noticiário político.

Os telejornais dedicam pouca atenção à vida interna dos partidos, talvez por partilhar da percepção de que, nas condições da política brasileira, eles são pouco relevantes. A principal exceção é o SBT Brasil, no período pré-eleitoral, com matérias que focam as disputas internas pela escolha dos candidatos. Movimentos sociais e sociedade civil se encontram quase ausentes do noticiário político, o que reforça a percepção de que a política é uma atividade a parte, fracamente conectada com outras esferas da vida social. As personagens do noticiário político estão, assim, relacionadas a uma representação redutora da política.

A literatura sobre "alienação política" aponta o problema da baixa integração dos indivíduos ao sistema político, vinculada a recursos cognitivos insuficientes e sentimento de impotência, que fazem com que se considerem apartados do universo da política (cf. o resumo desta li- 
teratura em Aldé, 2004:53-57). O noticiário jornalístico, ao mesmo tempo que fornece informações que contribuiriam para reduzir a alienação, reforça, pelo insulamento da política em instituições específicas, a impressão de "apartamento" do cidadão comum.

Por um lado, essa representação diminui a visibilidade já restrita de atores que poderiam produzir uma tensão com os limites atuais das instituições e do debate político, trabalhando para confirmar esses limites. De 2.134 matérias classificadas como "política brasileira", apenas 65 apresentaram alguma personagem vinculada a movimentos sociais e 19, a organizações não governamentais. Especialistas ligados às universidades (presentes em 17 matérias) e representantes de religiões organizadas (em 19) estão em situação similar. Por outro lado, essa representação redutora da política silencia o impacto de atores que não são propriamente políticos sobre o exercício da política pelos atores propriamente políticos. A despeito da inegável influência do poder econômico sobre a vida política, personagens ligadas a empresas privadas não apareceram em mais do que 74 - isto é, 3,2\% - dessas matérias e são apenas $45(7,7 \%)$ entre as 580 personagens presentes nas matérias da categoria "escândalo".

Entre as revistas, Veja e Época mostram perfis similares, ao passo que CartaCapital é ligeiramente desviante: dedica um pouco menos de espaço à categoria fait-divers $(27,7 \%$, contra $31 \%-33 \%$ das outras), mais ao noticiário internacional e muito mais à categoria "economia brasileira" (12,1\%, contra 3\%-5\% das outras). Isoladas as matérias de política, as diferenças ficam bem mais significativas - e o quadro que põe Veja e Época de um lado e CartaCapital do outro não descreve mais a situação.

Salta aos olhos como Veja concentra o noticiário político nos escândalos, numa proporção muito maior que suas concorrentes, como mostra a Tabela 2. Em qualquer um dos três períodos sob análise, Veja dedica uma proporção maior de suas páginas de política à cobertura dos escândalos, seguida por CartaCapital e, bem depois, pela Época. Para qualquer uma das três revistas, o noticiário sobre escândalos declina de período para período. Em Veja, cai de $57,2 \%$ das páginas sobre política, no período pré-eleitoral, para $12,2 \%$ no período pós-eleitoral; na Época, vai de 23,7\% para 5,3\%; e na CartaCapital, de 44,3\% para 8,1\%. Embora o corpus das revistas, no período pós-eleitoral, abranja os três primeiros meses do ano, caracterizados por um noticiário político mais "morno", esse fato dificilmente corresponde a toda a explicação. Ta- 
manho foco nos escândalos políticos no primeiro semestre de 2006 seguramente se relaciona às tentativas, por parte dos agentes políticos relevantes - aí incluída a própria mídia -, de moldar o cenário em que ocorreria a disputa eleitoral, meses depois.

Tabela 2

Distribuição do espaço do noticiário político, por revista e assunto (2006-2007)

\begin{tabular}{l|c|c|c}
\hline & Veja & Época & CartaCapital \\
\hline Poder Executivo & $10,5 \%$ & $14,9 \%$ & $15,1 \%$ \\
Poder Legislativo & $2,9 \%$ & $2,4 \%$ & $4,8 \%$ \\
Poder Judiciário & $1,3 \%$ & $1,1 \%$ & $2,5 \%$ \\
Escândalos & $42,6 \%$ & $12,7 \%$ & $28,6 \%$ \\
Eleições: pesquisas & $5,6 \%$ & $1,0 \%$ & $8,2 \%$ \\
Eleições: serviço & $3,8 \%$ & $2,5 \%$ & $3,5 \%$ \\
Eleições: debate & $7,9 \%$ & $28,1 \%$ & $12,9 \%$ \\
Vida partidária & $3,5 \%$ & $6,5 \%$ & $8,6 \%$ \\
Movimentos sociais & $1,0 \%$ & $2,6 \%$ & $3,7 \%$ \\
História & $1,9 \%$ & $2,7 \%$ & $3,1 \%$ \\
Outros/mix & $19,0 \%$ & $25,6 \%$ & $9,1 \%$ \\
\hline Total & $\mathbf{1 0 0 \%}$ & $\mathbf{1 0 0 \%}$ & $\mathbf{1 0 0 \%}$ \\
$\mathbf{n}$ & $\mathbf{6 3 5 , 8}$ & $\mathbf{4 6 8 , 6}$ & $\mathbf{4 4 9 , 7}$ \\
\hline
\end{tabular}

Fonte: Pesquisa Determinantes de gênero, visibilidade midiática e carreira política no Brasil.

Veja também se distingue pela menor atenção dada às ações do Poder Executivo, ao debate eleitoral e às movimentações internas aos partidos. Mas não se trata nem de uma polarização, em que ela fica de um lado e Época e CartaCapital do outro, nem de um continuum referida à posição relativa ao governo Lula, com Veja (mais oposicionista) numa extremidade, CartaCapital (mais governista) na outra e Época em posição intermediária. Isso faria crer que CartaCapital daria menos espaço aos escândalos políticos e mais aos atos do Poder Executivo do que Época, o que os dados não confirmam. A subcategoria "ações do Poder Executivo" ganha espaço praticamente idêntico nas duas publicações e, no que se refere aos escândalos, a proporção do noticiário político dedicada por CartaCapital, embora bem inferior à de Veja, é mais do que o dobro da de Época.

Embora a subcategoria "escândalos" reúna uma diversidade de matérias - de denúncias de corrupção em prefeituras municipais a nepotis- 
mo no Congresso Nacional -, 35,2\% delas envolviam o Poder Executivo Federal. O episódio que mais repercutiu foi a acusação contra o então ministro da Fazenda, Antônio Palocci, de ter chefiado um esquema de recebimento de dinheiro ilícito para o PT quando era prefeito de Ribeirão Preto, importante cidade do estado de São Paulo. Os desdobramentos da acusação, em especial a quebra ilegal do sigilo bancário de uma testemunha-chave contra Palocci, levaram à sua queda do ministério, em 27 de março de 2006, ou seja, no início do acompanhamento do noticiário.

Cerca de dois terços das matérias sobre escândalos incluem personagens que podem ser identificadas, com clareza, como porta-vozes do governo federal ou da oposição a ele. Veja é a única revista que apresenta mais matérias em que aparecem apenas porta-vozes do governo nela, em $48,4 \%$ das matérias em que tais personagens são identificadas, há representantes do governo, mas não da oposição, contra 13,3\% em Época e 5,4\% em CartaCapital. Veja também possui muito menos matérias só com porta-vozes oposicionistas: 4,4\%, enquanto nas outras revistas a proporção é de cerca de $20 \%$. Ao que parece, há uma contradição com a postura assumidamente contrária ao PT e ao governo Lula da revista Veja. Na etapa quantitativa da pesquisa não é possível explicar o aparente paradoxo, exceto por duas especulações. Primeiro, o enquadramento dado por Veja aos escândalos situa-os não como um momento da disputa entre governo e oposição, mas como um embate entre acusadores "neutros" (testemunhas, procuradores e policiais) e um réu (o próprio governo). Em segundo lugar, as explicações dadas por integrantes ou defensores do governo são veiculadas, mas, ao mesmo tempo, desqualificadas por meio de signos discursivos de ironia e suspeição. Esse é um recurso corrente no noticiário das revistas semanais e tem papel importante no noticiário de Veja. A ironia participa da produção do lugar de "guardião da consciência moral" que o jornalismo se atribui. Permite apresentar um julgamento moral sem que seja necessário fazer um "sermão" sobre o tema (Ettema e Glasser, 1998:87).

Apenas como contraponto, em qualquer um dos três telejornais, nas matérias sobre escândalos políticos em que é possível identificar porta-vozes do governo e/ou da oposição, há uma nítida maioria da presença de ambos - entre 58,3\% (Jornal da Band) e 70\% (Jornal Nacional). O SBT Brasil apresenta menos matérias em que há só oposição $(3,4 \%$, contra aproximadamente $11 \%$ dos outros) e o Jornal Nacional, menos matérias em que só aparecem porta-vozes do governo $(17,8 \%$, contra cerca 
de $32 \%$ dos outros), mas as diferenças são bem menos notáveis do que entre as revistas.

Assim como ocorre nos telejornais, no noticiário político das revistas há pequena presença de personagens vinculadas a movimentos sociais (aparecem apenas em 23 matérias, num universo de 823), organizações internacionais (em 13), forças armadas (em 15) e religiões organizadas (em 11). Há uma presença um pouco maior de organizações não governamentais, que surgem em 69 matérias (apenas oito delas publicadas na revista Veja), e sobretudo de empresas privadas (em 228 matérias, ou 27,7\% do total) e de acadêmicos (presentes em 114 matérias, 13,9\% do total), sem que se registrem disparidades dignas de nota entre as três publicações. Em suma, as revistas são um pouco mais abertas que os telejornais à presença, no noticiário político, de pessoas estranhas ao universo da política em sentido estrito, mas essa abertura se dá principalmente por meio da incorporação de porta-vozes das empresas e de especialistas ligados às universidades.

\section{AS PERSONAGENS DO NOTICIÁRIO}

Diante desse quadro de baixa presença de integrantes da sociedade civil, não é surpresa que as personagens do noticiário político provenham, em sua maioria, das instituições políticas em sentido estrito. Foram identificadas 1.724 diferentes personagens nas matérias de política dos telejornais, além de uma quantidade de "anônimos" (em geral, fontes ou testemunhas não identificadas ou populares entrevistados em enquetes). Entre as personagens, 27,3\% pertencem ao Poder Legislativo, seguido de perto pelo Executivo $(24,5 \%)$. As personagens populares foram $8,3 \%$ daquelas presentes nos telejornais, seguidas, então, por integrantes do Poder Judiciário $(4,1 \%)$ e técnicos $(3,6 \%)$. Um terço das personagens não é classificado em nenhuma dessas categorias.

Como esperado, o presidente da República e os outros candidatos à sua sucessão encabeçam a lista das personagens mais presentes, como mostra a Tabela 3. E é muito grande a pulverização da presença no noticiário dos telejornais - $68 \%$ das personagens, já excluídas as anônimas, aparecem em uma única matéria; $87,1 \%$ aparecem em menos de cinco. Muitas personagens aparecem eventualmente e são substituídas de acordo com a alternância de fatos e eventos. Mas o noticiário se concentra, de fato, em poucas personagens, que têm visibilidade continuada de acordo com o cargo e a posição que ocupam no campo político, o que 
confirma o resultado de pesquisas que definem o noticiário como institucionalista (Gomes, 2008:11).

Lula é, de longe, a personagem mais presente, com Geraldo Alckmin, Heloísa Helena e Cristovam Buarque seguindo-o, na mesma ordem em que terminaram classificados no primeiro turno das eleições presidenciais de 2006. Mesmo candidatos de partidos pequenos e com votação insignificante, como José Maria Eymael (0,07\% dos votos válidos) e Luciano Bivar (0,06\% dos votos válidos), integram a seleta lista das personagens com aparição em mais de cinquenta matérias dos telejornais ${ }^{7}$.

Tabela 3

Personagens do noticiário político dos telejornais, por número de matérias em que aparecem

(2006-2007)

\begin{tabular}{l|c}
\hline Nome & Matérias \\
\hline Luiz Inácio Lula da Silva & 612 \\
Geraldo Alckmin & 299 \\
Heloísa Helena & 137 \\
Cristovam Buarque & 119 \\
Antônio Palocci & 79 \\
Tarso Genro & 78 \\
Renan Calheiros & 70 \\
José Serra & 67 \\
Luiz Antonio Vedoin & 66 \\
Anthony Garotinho & 65 \\
Márcio Thomas Bastos & 62 \\
Ricardo Berzoini & 62 \\
José Maria Eymael & 51 \\
Luciano Bivar & 50 \\
Outros & 4.721 \\
Anônimos & 327 \\
\hline Total & 6.867 \\
\hline
\end{tabular}

Fonte: Pesquisa Determinantes de gênero, visibilidade midiática e carreira política no Brasil.

A lista reflete também a predominância do Poder Executivo no noticiário. Entre as catorze personagens mais presentes, seis disputaram a Presidência em 2006; outras quatro foram ministros (Palocci, Genro, Bastos e Berzoini). José Serra foi, sucessivamente, nos três períodos da 
pesquisa, postulante à candidatura presidencial pelo Partido da Social Democracia Brasileira (PSDB), candidato ao governo de São Paulo e governador de São Paulo. Anthony Garotinho tentou ser candidato à Presidência pelo Partido do Movimento Democrático Brasileiro $(\mathrm{PMDB})$ e boa parte de sua presença no noticiário se deve à greve de fome que iniciou como forma de pressionar a direção de seu partido. $\mathrm{O}$ único integrante da relação que deve sua presença sobretudo à atuação no Poder Legislativo é Renan Calheiros, presidente do Senado Federal. E Luiz Antonio Vedoin, por fim, é o único que não ocupava nem postulava mandato eletivo. Empresário, ele foi um dos pivôs do chamado "escândalo das sanguessugas" - um esquema de corrupção na venda de ambulâncias para o poder público -, que eclodiu em setembro de 2006.

Mas Lula é a única personagem que está muito presente nos três períodos - de fato, lidera as aparições nos noticiários em todos eles. Palocci, o segundo colocado no período pré-eleitoral, com 66 matérias, aparece em apenas 13 nos dois períodos restantes reunidos. Alckmin aparece em 55 matérias no período pré-eleitoral, já como postulante à Presidência pelo PSDB, em outras 243 no período eleitoral e uma única vez no pós-eleitoral. Melhor sorte que Heloísa Helena e Cristovam Buarque, que simplesmente somem do noticiário neste último período. Os protagonistas de escândalos também tendem a ter sua presença concentrada, sumindo do noticiário quando o caso ao qual estavam ligados sai da pauta.

As revistas apresentam uma quantidade maior de diferentes personagens nas matérias de política - são 2.477, além de 76 anônimos. Como nos telejornais, Lula é, de longe, a personagem mais presente. Mas o restante da lista dos mais presentes revela algumas discrepâncias entre os dois tipos de veículos (Tabela 4).

Geraldo Alckmin, o principal candidato da oposição às eleições presidenciais de 2006, que disputou o segundo turno contra Lula, é o segundo nome que mais aparece em matérias das revistas. Mas Heloísa Helena está muitas posições abaixo e Cristovam Buarque, presente em 31 matérias, nem figura entre as 19 personagens que estão em 40 ou mais matérias. Os candidatos dos partidos menores, então, aparecem entre uma e cinco vezes cada. O terceiro da lista das revistas é Fernando Henrique Cardoso, ex-presidente da República, que não ocupou ou disputou qualquer cargo eletivo no período sob análise. Outros dois ex-pre- 
Tabela 4

Personagens do noticiário político das revistas, por número de matérias em que aparecem

(2006-2007)

\begin{tabular}{l|c}
\hline Nome & Matérias \\
\hline Luiz Inácio Lula da Silva & 451 \\
Geraldo Alckmin & 219 \\
Fernando Henrique Cardoso & 151 \\
José Serra & 137 \\
José Dirceu & 111 \\
Antônio Palocci & 81 \\
Aécio Neves & 68 \\
Fernando Collor de Mello & 60 \\
Anthony Garotinho & 55 \\
Tarso Genro & 51 \\
Marcos Valério & 48 \\
Heló́sa Helena & 47 \\
Márcio Thomaz Bastos & 47 \\
Aló́sio Mercadante & 46 \\
José Sarney & 44 \\
Aldo Rebelo & 43 \\
Ciro Gomes & 41 \\
Tasso Jereissati & 4.721 \\
Antônio Carlos Magalhães & 46 \\
Outros & \\
Anônimos & 706 \\
\hline Total & 41 \\
\hline & \\
\hline
\end{tabular}

Fonte: Pesquisa Determinantes de gênero, visibilidade midiática e carreira política no Brasil.

sidentes figuram na lista - Fernando Collor de Mello, que chamou atenção por sua candidatura e eleição ao Senado, após ter recuperado os direitos políticos; e José Sarney, que se reelegeu senador numa apertada disputa no Amapá. Aparecem com destaque também outros parlamentares (Mercadante, Rebelo, Gomes, Jereissati e Magalhães). E os protagonistas de escândalos - o ex-ministro José Dirceu e o empresário Marcos Valério - ligam-se não às denúncias mais recentes, mas ao "mensalão", que eclodira no primeiro semestre de 2005. 
A maior parte das personagens anônimas está na revista Veja (55, isto é, 72,4\% dos anônimos). CartaCapital apresenta dez personagens anônimas e Época traz 11. A presença dos anônimos concentra-se, sobretudo, nas matérias da categoria "escândalos", na qual estão mais da metade dos anônimos de Veja. Muitas das denúncias de corrupção noticiadas nessas matérias são atribuídas a fontes não nomeadas. Esse recurso é amplamente utilizado por Veja, fazendo parte de trinta matérias sobre "escândalos". Está presente em frequência reduzida na CartaCapital, em apenas cinco matérias dessa categoria, e não foi encontrado na revista Época.

Mesmo no caso de Veja, porém, não são números discrepantes daqueles apontados em pesquisas internacionais. Há fontes anônimas em $15,7 \%$ das matérias de política (e $24,2 \%$, se isoladas apenas as referentes a escândalos). Elas estariam presentes em cerca de 15\% das matérias do Times londrino, em $25 \%$ do New York Times e muito acima desses patamares no jornalismo diário português (Sousa, 2002:6).

Os dados sugerem que o noticiário das revistas é menos prisioneiro dos cargos formais do campo político - embora os ocupantes e candidatos aos principais cargos tenham destaque, como nos telejornais, também há espaço para indivíduos que detêm alto capital político, mas que não estão, no momento, em tais posições. Além disso, esse noticiário também possui uma "memória" maior, retomando acontecimentos dos meses anteriores. Aqui, há uma diferença que, sem ser gritante, é estatisticamente significativa: Fernando Henrique Cardoso aparece mais em CartaCapital (que responde por 66 das 151 matérias em que ele é citado), ao passo que José Dirceu está mais presente em Veja (63 de 111 matérias). Apesar de a simples análise quantitativa não permitir chegar a conclusões, é razoável supor que as menções ao ex-presidente lembravam aos leitores de CartaCapital que o governo anterior padecia das mesmas mazelas que a oposição agora atribuía à gestão de Lula, ao mesmo tempo que concedia a ele o papel de porta-voz do PSDB. De fato, a presença mais concentrada de Fernando Henrique Cardoso na CartaCapital é nas categorias "escândalos" e "vida partidária", com 18,2\% das matérias em cada uma. E o nome de Dirceu associava-se ao "mensalão", com o qual Veja fustigava a administração do PT. Nesse caso, a concentração na categoria "escândalos" é bem maior, com $38,1 \%$ das matérias da revista em que Dirceu esteve presente. 
O contraste entre as tabelas 3 e 4 pode levar a crer que o noticiário das revistas é pulverizado entre mais personagens, mas trata-se de um efeito do desenho da pesquisa. São contadas as matérias em que cada personagem aparece, independentemente de ser uma referência exclusiva, central ou lateral. As revistas tendem a ter matérias maiores, que apresentam, em média, 9,1 personagens, ao passo que os telejornais apresentam um número maior de matérias, mas menores, com, em média, 2,9 personagens cada. As 612 matérias com Lula indicam que o presidente apareceu ou foi citado em $26,2 \%$ das matérias de televisão, mas as 451 matérias com ele nas revistas correspondem a 54,8\% do total.

Nos telejornais, há um percentual maior de personagens com posição favorável ao governo federal $(24,5 \%)$, comparativamente aos $19 \%$ de oposicionistas e aos $17,7 \%$ que assumem posição neutra ou ambígua nas matérias. As matérias apresentam também uma presença acentuada de personagens ligadas ao PT ( $26,7 \%$, ou 1.833 personagens). Vale lembrar que Lula é responsável por um terço dessa presença. Esses dados - tanto os de posição das personagens do governo federal quanto o da presença do PT nas matérias - refletem a visibilidade ampla de integrantes do governo federal no noticiário, sobretudo do presidente Lula e de seus ministros, e não resultam, necessariamente, em matérias que apresentam posições favoráveis ao governo. A presença de personagens favoráveis ao governo federal em matérias de "escândalo", por exemplo, pode significar uma visibilidade negativa para o governo federal. A maior concentração das personagens "governistas" no noticiário político é na categoria "escândalos", com 459 ou 27,4\%, contra 261 ou $19,9 \%$ das oposicionistas. A proporção se inverte quando se observa a categoria "debate eleitoral", que apresenta a maior concentração de "oposicionistas", com 642 ou $49 \%$ de aparições, quase o dobro da presença de governistas nessa mesma categoria (350 ou 20,9\%). A concentração das personagens relacionadas ao PT nas matérias de "escândalo" é ainda maior, com 802 ou 43,8\% da presença do partido nos telejornais.

O segundo partido com mais personagens no noticiário é o PSDB, com $673(9,8 \%)$, seguido pelo PMDB, com 575 (8,4\%), e pelo Partido da Frente Liberal (PFL)/Democratas (DEM), com 254 (3,7\%). Como no caso de Lula, Alckmin é responsável por boa parte da frequência de personagens do PSDB, nesse caso, pouco menos da metade das citações. E a maior presença do PSDB entre as categorias temáticas é no "debate 
eleitoral", acompanhando os dados sobre concentração de "oposicionistas" entre os temas das matérias. O Partido Democrático Trabalhista (PDT), o Partido Socialismo e Liberdade (PSOL) e o Partido Trabalhista Brasileiro (PTB) concentram, cada um, pouco mais que $2 \%$ das personagens. Não há diferenças significativas entre os telejornais.

As revistas repetem, grosso modo, a distribuição detectada nos telejornais, mas há uma concentração menor nas personagens favoráveis ao governo e nas personagens ligadas ao PT, com um percentual maior de personagens ligadas ao PSDB. O PT concentra 1.563 personagens, ou 20,9\% do total, e Lula é, como nos telejornais, responsável por pouco menos que um terço das citações. Alckmin, por sua vez, representa um quarto das $889(11,9 \%)$ personagens vinculadas ao PSDB. Na sequência, vêm o PMDB, com 512 (6,8\%), e o PFL/DEM, com 306 (4,1\%). Os demais partidos não ultrapassam os $2 \%$. Mais uma vez, a maior presença das personagens ligadas ao PT é na categoria "escândalos", em que se encontram 252 , ou $38,5 \%$ delas, mais do que o dobro do percentual de concentração das personagens do PSDB nessa categoria, 18,1\% (que equivalem a 161 personagens). Como nos telejornais, não há diferenças significativas entre as revistas.

Outro dado relativo ao perfil das personagens presentes no noticiário é a grande concentração em uma das unidades da Federação, São Paulo. No caso dos telejornais, 31,3\% das personagens são paulistas. O estado do Rio de Janeiro vem na sequência, com apenas $5 \%$ das personagens, seguido por Alagoas (3,6\%), Rio Grande do Sul (2,9\%) e Minas Gerais $(2,7 \%)$. A concentração em São Paulo se repete nas revistas, com 26,8\% das personagens. Rio de Janeiro, com 4,3\%, e Minas Gerais, com 3,8\%, vêm na sequência, mas a concentração entre os estados atende a um mesmo padrão. Com exceção de Alagoas e Bahia, nenhum estado da região Nordeste apresenta mais de $2 \%$ das personagens. Aqui também é possível sustentar que os veículos analisados apresentam padrões de visibilidade que são, em vários aspectos, homogêneos. Atendem a compreensões comuns sobre a relevância dos temas, espaços e atores, confirmando representações da política que transcendem as diferenças de posicionamento em relação a partidos e disputas específicas.

\section{AS VOZES}

A concentração em dimensões da política (poder e âmbito aos quais pertencem as personagens) e em posições e partidos políticos deve ser 
lida em sua relação com um outro dado importante, o acesso à voz, um elemento fundamental de diferenciação entre aqueles que estão presentes no noticiário. É da natureza da política a busca pelo espaço de fala - e o líder político, o representante, pode ser entendido como o porta-voz daqueles que lhe dão um mandato, formal ou não (Bourdieu, 1986). Ou, como disse um deputado de ficção, personagem não dos telejornais, mas de um romance: "A política odeia o silêncio" (Tezza, 2004:95).

Começando com os telejornais, em 57,4\% dos casos, a personagem é apenas citada por um repórter, pelo apresentador do noticiário ou, mais raramente, por outra personagem. Os $42,6 \%$ restantes têm voz. Essas presenças "com voz" foram diferenciadas, de acordo com o conteúdo do que era dito, em quatro categorias "sonoras":

a) Sonora com argumento: quando o entrevistado ${ }^{8}$ afirma que é contra ou a favor de determinado projeto (ou candidatura, ou situação etc.), acrescentando ainda, de forma taquigráfica, argumentos que sustentem sua posição;

b) Sonora com posição: quando o entrevistado afirma que é contra ou a favor de determinado projeto, sem aduzir argumentos em favor de sua posição;

c) Sonora técnico-descritiva: quando o entrevistado limita-se a explicar um processo (por exemplo, a tramitação de um projeto legislativo), sem indicar uma posição quanto à sua substância;

d) Sonora irrelevante: quando a declaração do entrevistado tem caráter meramente anedótico.

Foram identificadas 2.960 sonoras nas matérias de política, 50,3\% das quais com argumento, 28,4\% com posição, 8,4\% técnico-descritivas e $12,9 \%$ irrelevantes. As sonoras com argumento alcançaram duração média de 14,8 segundos, um pouco maior do que aquelas com posição (média de 12,3 segundos) ou técnico-descritivas $(12,4)$ e bem a frente das irrelevantes, que duraram, em média, 6,7 segundos.

Lula, o mais assíduo no noticiário, foi apenas citado por repórter ou apresentador em 57,8\% das matérias em que apareceu. Isso relativiza sua presença. Ele aparece em mais do que o dobro de matérias em relação a Geraldo Alckmin, mais de quatro vezes em relação a Heloísa Helena, mas suas 197 sonoras estão bem próximas das 172 de Alckmin e não chegam a três vezes as 75 da candidata do PSOL. 
A menor presença de Lula foi no Jornal Nacional, em que fez parte de 172 matérias, enquanto participou de 232 matérias no Jornal da Band e 214 no SBT Brasil. Nesse caso, a presença mais qualificada de Lula, que teve mais voz no Jornal Nacional - as sonoras de Lula estão em 46,5\% das reportagens com ele no Jornal Nacional, contra 26,7\% das reportagens em que esteve presente no Jornal da Band e 25,7\% no SBT Brasil não relativiza sua baixa presença. Afinal, Alckmin esteve presente de maneira mais homogênea entre os telejornais (110 reportagens no Jornal da Band, 100 no Jornal Nacional e 96 no SBT Brasil), mas teve também um percentual maior de sonoras no Jornal Nacional (75\%, contra 52,1\% no SBT Brasil e 42,7\% no Jornal da Band).

Nos telejornais, as personagens que tiveram acesso à voz com maior frequência foram os integrantes do Legislativo $(29,1 \%)$ e do Executivo (20\%), seguidos pelos "populares", que representaram 17,7\% das sonoras, apesar de serem apenas $8,2 \%$ das personagens. Isso se explica pelo fato de que, destinados a dar colorido ao noticiário, mas sem contribuir efetivamente ao debate, os populares raras vezes são citados por terceiros. Os técnicos foram $6,8 \%$ das personagens com voz e os integrantes do judiciário 3,8\%. Mas a duração média das sonoras relativiza a presença dos populares. É a menor entre os grupos, com 7,4 segundos. A duração média da sonora das personagens do Executivo é a maior, com 17,7 segundos, acentuando ainda mais sua presença. Técnicos, integrantes do Judiciário e do Legislativo apresentam sonoras com duração média de 11,4 a 12,3 segundos.

Para analisar a distribuição do acesso à voz entre as personagens das revistas, elas foram divididas entre aquelas que foram apenas mencionadas nas matérias, sem voz $(74,4 \%)$, aquelas que tiveram voz direta, isto é, que tiveram palavras suas citadas nas matérias entre aspas $(20,1 \%)$ e aquelas que tiveram sua fala presente nas matérias, porém mencionada de forma indireta pelo autor do texto (5,5\%). Assim, em apenas $25,6 \%$ dos casos as personagens presentes nas matérias "falam".

Lula, que teve a maior presença também entre as personagens das revistas, foi apenas citado (sem voz) em $76,1 \%$ das matérias, enquanto Alckmin em 80,9\% das matérias. De modo geral, a presença menor das personagens é acompanhada de um decréscimo no percentual de matérias em que têm acesso à voz. Fernando Henrique Cardoso, o terceiro em número de citações nas revistas, é apenas citado (sem voz) em 
$84,1 \%$ das entradas. José Serra, que vem na sequência, aparece sem voz em 91,2\% delas. Heloísa Helena é uma exceção. Sua presença é aproximadamente dez vezes menor que a de Lula e cinco vezes menor que a de Alckmin, mas ela tem voz, direta ou indireta, em 29,7\% das matérias (sendo apenas citada nas outras 70,3\%). Nesse caso específico, sua presença reduzida corresponde a uma concentração no período eleitoral (quando foram publicadas 89,4\% das matérias em que apareceu), o que explica que a baixa presença não corresponde a um decréscimo maior de voz. Outro caso, o de Marta Suplicy, mostra uma situação diferente. Sua presença em 38 matérias, apenas nove a menos que Heloísa Helena, foi menos concentrada, apesar de ter tido $50 \%$ de sua presença no período pós-eleitoral, quando se discutia sua indicação como ministra do segundo governo de Lula. Mas seu acesso à voz foi praticamente nulo: ela foi apenas citada, sem voz, em 37 das 38 matérias em que apareceu.

Lula e Alckmin, os dois atores com maior presença no noticiário das revistas (acompanhando, nesse caso, o que se viu nos telejornais), estão associados, de maneira mais concentrada, a temas diferentes. Retirando-se a categoria temática "outros/mix", em que estão presentes as matérias que tratam de diversos temas (com 30,2\% da presença de Lula e $28,8 \%$ da de Alckmin), a concentração maior de Lula é na categoria "escândalos", com 88 entradas (19,5\%). A de Alckmin, por sua vez, é na categoria "debate eleitoral", com 60 entradas (27,4\%). A distribuição entre as revistas é desigual. Mais da metade das matérias da categoria "escândalos" em que Lula aparece (48) foram publicadas na revista Veja. No caso de Alckmin, diferentemente, há uma distribuição bastante similar entre as revistas na categoria "debate eleitoral"; e, na categoria "escândalos", em que estão trinta $(13,7 \%)$ das matérias em que aparece, a distribuição em Veja e CartaCapital é semelhante, com 12 e 11 matérias, respectivamente.

Entre as 1.914 personagens que tiveram voz nas revistas, a maior concentração foi das vozes técnicas $(29,5 \%)$, diferentemente do que ocorre nos telejornais. Esse dado está relacionado ao perfil das revistas: o espaço dedicado às matérias nas revistas semanais permite não apenas uma variedade maior de personagens, em comparação aos telejornais, mas também o investimento em "análises" que são respaldadas em personagens reconhecidas como detentoras de conhecimentos específicos. Como nos telejornais, há uma hierarquia favorável ao Executivo na presença dos três poderes que constituem o Estado: Executivo 
(16,2\%), Legislativo (14,7\%) e Judiciário $(7,7 \%)$. Os "populares", que são apenas $0,7 \%$ das personagens presentes nas revistas, representaram $1,4 \%$ das personagens que tiveram voz nas matérias. É muito menos do que o percentual de "populares" com voz nos telejornais. Mais uma vez, temos aqui um traço diferencial entre o perfil do noticiário nos telejornais e nas revistas. Os "populares" aparecem, com frequência, legitimando os ângulos assumidos pelo noticiário nos telejornais. A baixa duração dos seus soundbites confirma sua posição de testemunhas pouco qualificadas. Sua presença ampla, por outro lado, está relacionada ao modo como o jornalismo televisivo opera com os rituais da imparcialidade e produz vínculos entre o noticiário e seu público amplo. Nas revistas, isso é bem mais raro. Pode-se dizer que no noticiário impresso das revistas semanais, voltado para um público menor e menos heterogêneo do que nos telejornais, os procedimentos de legitimação passam mais frequentemente pelo discurso técnico e pelos rituais da imparcialidade consagrados, que dão voz (mesmo que de maneira diferenciada) aos diferentes participantes de uma mesma contenda.

Outro dado que confirma essas observações é a relação entre os "populares" e as categorias temáticas no noticiário político. A maior presença nos telejornais faz com que estejam também distribuídos de maneira menos concentrada do que nas revistas e façam parte de uma diversidade maior de matérias. Nas revistas, a maior concentração dos "populares" é na categoria "debate eleitoral" $(44,6 \%)$. Os "populares" são, em sua quase maioria, eleitores que opinam sobre candidatos e temas da agenda eleitoral. Essa categoria é seguida de longe pelas"ações do Poder Executivo" (14,3\%) - vale observar que a presença dos "populares" nas matérias sobre o Legislativo é de apenas 1,8\%, o que corresponde a apenas uma em um universo de 56 personagens. Nos telejornais, a maior concentração dos "populares" está nas matérias que tratam de mais de uma temática ao mesmo tempo, presentes na categoria "outros/mix" (37,8\%), seguida por "movimentos sociais/sociedade civil" (13,9\%) e "ações do Poder Executivo" (12,3\%). Novamente, a concentração dos "populares" nas matérias sobre o Legislativo é mais baixa, ainda que não seja tão pequena quanto nas revistas: são $7,6 \%$, ou 43, em um universo de 563.

A observação das ocupações associadas às personagens confirma, novamente, a concentração do noticiário em poucos perfis, bastante específicos. No noticiário político de telejornais e revistas, estão presentes, predominantemente, personagens que ocupam cargos nos altos esca- 
lões do Poder Executivo e Legislativo. Entre as dez ocupações mais presentes no noticiário das revistas, apenas uma, a de "cientista políti$\mathrm{co}^{\prime \prime}$, não faz parte do campo político estrito senso (ainda que apareça em relação direta com as formas de existência atuais do campo, em análises que legitimam e naturalizam seus limites). No caso dos telejornais, estão entre as dez mais citadas também as ocupações de empresário e advogado.

\section{UM MUNDO MASCULINO}

A visibilidade ampliada da política institucional reforça uma compreensão dos limites da política - do campo político, dos debates e das personagens que são entendidas como pertencentes a esse campo e participantes legítimas desses debates. O noticiário de telejornais e revistas se concentra em personagens que têm características específicas e pertencem ao campo político estrito senso.

As personagens presentes no noticiário político são predominantemente masculinas. As mulheres são apenas 12,6\% das personagens presentes nos telejornais e $9,6 \%$ das personagens das revistas, confirmando sua posição de subalternidade na política institucional, que é tomada amplamente como $a$ política pelos telejornais. Essa presença varia pouco entre telejornais e revistas. Nas revistas, CartaCapital apresenta um percentual levemente menor de mulheres, $8,7 \%$, pouco menos de um ponto percentual abaixo dos 10-10,1\% de Veja e Época. Mas é na CartaCapital que as mulheres têm maior acesso à voz. São 33,2\%, ou 64 , entre as 193 personagens femininas das revistas. Na Época, têm voz 50 entre as 222 personagens femininas, 22,5\% delas, portanto; e na Veja, que tem o menor percentual de personagens femininas com voz, elas são 54 , isto é, 17,6\% em um universo de 307 mulheres que estiveram na revista nos quase dez meses que constituíram nossa amostra. Entre os telejornais, o SBT Brasil apresenta um percentual menor de personagens femininas (11,2\%), pouco abaixo dos $13,4 \%$ e $13 \%$ do Jornal da Band e do Jornal Nacional. É esse último, no entanto, que apresenta o maior percentual de mulheres com voz, $64,2 \%$, bastante acima do percentual geral de $46,7 \%$ de sonoras nesse telejornal. O Jornal da Band e o SBT Brasil apresentam, respectivamente, 58,5\% e 51,7\% de personagens femininas com voz.

A presença reduzida das mulheres nos telejornais é acompanhada por maior acesso à voz. Neles, 59,4\% das mulheres presentes nas matérias 
tiveram voz, contra 40,5\% dos homens. Vale lembrar que isso significa que 516 mulheres tiveram voz nas matérias dos telejornais, enquanto 2.444 homens estiveram presentes com acesso à voz - ou seja, elas permanecem como uma reduzida minoria. Parte dessa diferença pode ser creditada ao fato de que há, entre as mulheres, uma proporção maior de personagens "populares" (que, como visto, tendem a aparecer falando com maior frequência). Retirados os "populares", a proporção de personagens com voz cai para $45,1 \%$ entre as mulheres e $38,7 \%$ entre os homens.

Por outro lado, a duração média dos soundbites das mulheres é significativamente menor que a dos homens, 10,2 segundos para elas e 13,4 segundos para eles. A diferença torna-se menos expressiva com a exclusão das personagens "populares", quando a duração média dos soundbites delas sobe para 13 segundos e a deles, para 14,1 segundos.

Uma vez presentes nas revistas, homens e mulheres têm acesso semelhante à voz. Entre os homens, 25,8\% têm voz direta ou indireta, pouco acima dos $23,3 \%$ das mulheres que têm esse mesmo tipo de presença no material - lembrando que isso significa um total de 1.746 personagens masculinas com acesso à voz, mais de dez vezes o número de mulheres com voz, que é de 168 . A maior parte das personagens, homens $(74,2 \%)$ e mulheres $(76,7 \%)$, é apenas citada.

Nesse aspecto, a pouca presença de integrantes dos movimentos sociais e seu contraponto, a presença daqueles que possuem destaque nos partidos e nos três poderes, sobretudo no Executivo, colabora para a marginalidade das mulheres no noticiário político. A presença das mulheres é mais frequente nos movimentos sociais e em espaços alternativos de ação política, como o orçamento participativo e os conselhos gestores, do que no parlamento ou na chefia de ministérios. Estão também relacionadas de maneira mais estreita a temáticas que têm menor relevância no noticiário. Quando o noticiário político se volta quase exclusivamente para o campo político estrito senso, ignorando outros espaços e formas de fazer política, reforça também a compreensão de que as mulheres não fazem política.

A quantidade de personagens masculinas é tão largamente superior à de personagens femininas que, mesmo quando se observa o pertencimento a grupos sociais nos quais seria possível esperar uma concentração maior das mulheres, os números são ainda a explicitação da sua sub-representação na cobertura jornalística. Entre 91 personagens in- 
tegrantes de movimentos sociais que aparecem nos telejornais, apenas oito são mulheres; de 32 porta-vozes de organizações não governamentais (ONGs), só cinco são mulheres; e de 31 personagens vinculadas a universidades, as mulheres são seis. Nas revistas, os números são similares: há seis mulheres entre 46 representantes de movimentos sociais; outras seis entre 82 representantes de ONGs; e 24 num total de 194 acadêmicos. Ou seja: o noticiário político, em revistas e na televisão, deprime a presença das mulheres mesmo quando seleciona suas personagens dentro de organizações que já se mostram mais permeáveis a elas.

Quando se observa a distribuição de homens e mulheres entre diferentes tipos de personagens, a maior diferença favorável a elas está entre os "populares", que incluem justamente aquelas que não estão associadas a competências específicas nas matérias e são, por outro lado, identificadas a posições de menor centralidade (na política e no noticiário). Nos telejornais, isso significa uma concentração de $28,7 \%$ das personagens femininas contra apenas $5,2 \%$ das personagens masculinas. Mesmo assim, o número de homens continua a ser maior do que o de mulheres: elas são 249 e eles 314 personagens populares. Nas revistas, a diferença percentual é bem menos acentuada: são 18 mulheres, ou $2,5 \%$, e 38 homens, ou $0,5 \%$.

A distribuição irregular de homens e mulheres entre as categorias temáticas indica um aspecto importante nesses dados: a convivência entre a representação desvantajosa das mulheres na cobertura jornalística e os estereótipos de gênero, o que reforça a posição marginal da mulher no campo político. Assim, a pouca visibilidade é acompanhada de uma presença associada a temáticas de menor relevância, segundo a hierarquia interna dos noticiários e do campo político. Deslocando a análise novamente para o conjunto do noticiário - e não a restringindo às matérias sobre política brasileira -, percebe-se a concentração das mulheres num universo de questões que está mais próximo da esfera privada.

Desse modo, nos telejornais, elas aparecem sobretudo nas matérias de fait-divers, que reúnem $18,6 \%$ das personagens femininas - mais do que o dobro da concentração das personagens do sexo masculino na mesma categoria (ver Tabela 5). Seguem-se três categorias, com proporções bastante próximas, reunindo cada uma por volta de 15\% das mulheres nos telenoticiários: as matérias de polícia, nas quais, no entanto, elas 
estão com mais frequência na posição de vítimas do que de perpetradoras ou investigadoras; as matérias de cidades, em que elas aparecem sobretudo na condição de consumidoras ou usuárias de serviços públicos; e as matérias de política brasileira.

Tabela 5

Distribuição da presença de personagens femininas e masculinas nos telejornais

(2006-2007)

\begin{tabular}{|c|c|c|}
\hline & Mulheres & Homens \\
\hline Cidades/cotidiano & $15,0 \%$ & $8,5 \%$ \\
\hline Ciência/tecnologia & $1,8 \%$ & $1,3 \%$ \\
\hline Desastres & $3,7 \%$ & $3,1 \%$ \\
\hline Ecologia/meio ambiente & $1,8 \%$ & $1,6 \%$ \\
\hline Economia brasileira & $5,0 \%$ & $3,5 \%$ \\
\hline Educação & $3,0 \%$ & $1,0 \%$ \\
\hline Esportes & $4,5 \%$ & $13,3 \%$ \\
\hline Fait-divers/variedades & $18,6 \%$ & $8,8 \%$ \\
\hline Internacional & $7,6 \%$ & $9,1 \%$ \\
\hline Lições de vida & $1,3 \%$ & $0,6 \%$ \\
\hline Polícia & $15,5 \%$ & $14,3 \%$ \\
\hline Política brasileira & $14,4 \%$ & $30,7 \%$ \\
\hline Previsão do tempo & $0,1 \%$ & $0,0 \%$ \\
\hline Saúde pública & $4,0 \%$ & $1,5 \%$ \\
\hline Segurança pública & $2,9 \%$ & $2,3 \%$ \\
\hline Outros & $0,8 \%$ & $0,4 \%$ \\
\hline Total & $\begin{array}{c}100 \% \\
\mathrm{n}=6.005\end{array}$ & $\begin{array}{c}100 \% \\
\mathrm{n}=19.563\end{array}$ \\
\hline
\end{tabular}

Fonte: Pesquisa Determinantes de gênero, visibilidade midiática e carreira política no Brasil.

As personagens masculinas, por sua vez, concentram-se no noticiário político, seguido de polícia, esportes, internacional e, só então, fait-divers. Mas convém lembrar que a Tabela 5 apresenta os percentuais dentro de cada sexo. Assim, mesmo nas categorias que concentram mulheres em proporção bem maior do que homens, eles são majoritários. Os 18,6\% de mulheres em fait-divers contra 8,8\% de homens, por exemplo, significam, em números absolutos, 1.119 personagens femininas diante de 1.718 masculinas $^{9}$. No caso das matérias sobre política brasileira, categoria em que a concentração é muito maior do lado dos homens, os 
dados apontam que apareceram quase sete personagens do sexo masculino para cada uma do sexo feminino. Se as personagens "populares" são excluídas, essa relação ultrapassa nove para uma.

Nas revistas, há uma maior concentração tanto de homens quanto de mulheres na categoria fait-divers. Mais da metade das mulheres e de um terço dos homens que nelas aparecem estão em matérias classificadas como variedades (Tabela 6). Para ambos os sexos, a categoria seguinte de maior participação é "política brasileira", mas aí a concentração relativa de homem é muito maior $(25,6 \%$, mais do dobro do que o percentual verificado para as mulheres). O viés é ainda mais forte do que nos telejornais: são 9,4 homens para cada mulher no noticiário político das revistas semanais.

Tabela 6

Distribuição da presença de personagens femininas e masculinas nas revistas semanais

(2006-2007)

\begin{tabular}{l|c|c}
\hline & Mulheres & Homens \\
\hline Cidades/cotidiano & $3,7 \%$ & $3,7 \%$ \\
Ciência/tecnologia & $0,7 \%$ & $0,6 \%$ \\
Desastres & $0,7 \%$ & $0,7 \%$ \\
Ecologia/meio ambiente & $1,7 \%$ & $3,7 \%$ \\
Economia brasileira & $2,0 \%$ & $0,7 \%$ \\
Educação & $1,3 \%$ & $2,9 \%$ \\
Esportes & $5,0 \%$ & $9,7 \%$ \\
Fait-divers/variedades & $52,6 \%$ & $33,4 \%$ \\
Internacional & $1,1 \%$ & $0,6 \%$ \\
Lições de vida & $3,7 \%$ & $3,7 \%$ \\
Polícia & $1,6 \%$ & $1,4 \%$ \\
Política brasileira & $11,1 \%$ & $25,6 \%$ \\
Saúde pública & $1,1 \%$ & $0,8 \%$ \\
Segurança pública & $1,5 \%$ & $1,8 \%$ \\
Outros & $12,4 \%$ & $12,9 \%$ \\
\hline Total & $\mathbf{1 0 0 \%}$ & $\mathbf{1 0 0 \%}$ \\
& $\mathbf{n}=\mathbf{6 . 4 8 8}$ & $\mathbf{n}=\mathbf{2 6 . 3 9 4}$ \\
\hline
\end{tabular}

Fonte: Pesquisa Determinantes de gênero, visibilidade midiática e carreira política no Brasil.

Há um paralelo, no caso dos telejornais ${ }^{10}$, entre mulheres e negros, dois grupos sociais sub-representados no noticiário. Os negros são apenas $9,2 \%$ das personagens das matérias de política dos telejornais analisados. A análise do pertencimento das personagens a grupos sociais 
mostra que há maior presença dos negros entre os integrantes de movimentos sociais (são 27,5\%, representando 18,3 pontos acima do percentual geral de personagens negras, uma diferença considerada importante de acordo com os testes de significância estatística).

De modo complementar, a associação entre cor e poder mostra que a maior concentração de negros, como no caso das mulheres, está entre os "populares". Nos telejornais, 31,8\% dos "populares" são negros (22,6 pontos acima do percentual geral de personagens negras), enquanto só $54,2 \%$ são brancos ( 29,8 pontos abaixo do percentual geral de personagens brancas). Além disso, os negros apresentam-se ainda mais sub-representados entre as personagens vinculadas ao Poder Executivo, sendo apenas 3\% delas.

\section{CONCLUSÃO}

O que é a política, vista por um telespectador de telejornais ou por um leitor de revistas semanais? Em grande medida, ela se constitui naquilo que os meios lhe apresentam. Se, "para a maioria das pessoas, só existem dois lugares no mundo: o lugar onde elas vivem e a televisão", como diz uma personagem do romance Ruído Branco (DeLillo, 1987:69), está claro que a política pertence à segunda esfera. É um mundo de homens de gravata, diferenciado e distante da gente comum.

Pierre Bourdieu diz que os regimes representativos contemporâneos vivem uma permanente tensão entre o caráter formalmente democrático do sistema político e seu funcionamento real, que é censitário. A resolução desta tensão exige que muitos se abstenham "voluntariamente" da ação política, introjetando sua própria atribuição de incompetência (Bourdieu, 1979:464). É possível dizer que os meios de comunicação de massa contribuem para esse sentimento de incompetência, ao construir a política como universo separado, de acesso limitado a uns poucos e fracamente conectado com outras esferas sociais. No entanto, pode-se pensar que isso aumenta a importância dos próprios meios de comunicação, que apresentam a si mesmos como canais privilegiados de acesso a essa esfera e como tradutores competentes daquilo que nela se dá.

Assim, a política, nos telejornais e revistas semanais, é um campo restrito, associado às atividades e competências de determinados atores sociais. A oposição entre profissionais - que detêm posições no campo político ou são reconhecidos como distintos em sua competência para 
analisá-lo - e profanos é acompanhada de um reforço às hierarquias internas do campo político. Isso significa que, além de consagrar como atores políticos capazes de emitir opinião e participar do debate midiático aqueles que já fazem parte do campo político em sentido estrito, o jornalismo confere visibilidade justamente aos atores que já possuem recursos para se fazer ver, de acordo com os valores e hierarquias vigentes no campo.

O enfoque assumido pela pesquisa evidencia o fato de que, ao mesmo tempo que podem optar por um ou outro candidato, por uma ou outra plataforma política, os meios de comunicação de massa compartilham, em linhas gerais, uma compreensão sobre o que é a própria política: qual seu espaço, quais seus agentes. Essa compreensão é comum a veículos que apresentam opções político-partidárias diferenciadas ou que interagem de maneiras distintas com os cânones da imparcialidade jornalística. Pode permanecer enquanto os veículos modificam suas posições, de acordo com aspectos conjunturais e relativos a determinadas disputas.

A cobertura política confirma que tomar parte da política é possível para aqueles que têm um perfil específico, afinado a exigências e competências que, efetivamente, excluem a maior parte dos cidadãos. A visibilidade diferenciada dos temas que compõem a agenda da mídia está relacionada ao entendimento do que é politicamente relevante. E essa relevância se conecta, por sua vez, à centralidade assumida por atores e práticas políticas específicos. Nesse sentido, agenda e concessão de voz são dois aspectos de uma compreensão fundamental, a de que a política democrática é feita em determinados espaços e por determinados atores, ainda que suas práticas sejam, rotineiramente, submetidas ao escrutínio da população em geral. Nesse caso, o que é alvo da crítica no jornalismo não é um modo de funcionamento que concentra poder e reproduz clivagens e hierarquias sociais (de classe, de gênero e de raça), mas um mau funcionamento que faz com que os atores desempenhem mal seu papel de elites dirigentes. Um exemplo disso é que as matérias de escândalos jogam luz sobre comportamentos entendidos como desviantes, mas não sobre padrões estruturantes das relações entre Estado e poder econômico no capitalismo.

Na mídia, os atores políticos são aqueles que já possuem cargos públicos eletivos ou de confiança (especialmente no Executivo e no Legislativo federais), são homens e, comprovadamente, no caso dos telejor- 
nais, e especulativamente, no caso das revistas, são brancos. A política é, então, o espaço habitado por esses atores e se faz das relações entre eles, com menor ou maior grau de "aprovação" na própria cobertura. Na mídia, como nas esferas institucionais de representação política, a universalização que caracteriza a democracia convive com a exclusão da maior parte dos cidadãos dos espaços e posições que lhes conferem a possibilidade de decidir, emitir opiniões e fazer ouvir e ver suas perspectivas, isto é, seu entendimento sobre quais são as questões para eles relevantes e como deveriam ser conduzidas. À maioria dos cidadãos em um nicho que inclui os próprios espectadores e leitores - cabe acompanhar o jogo. Isso fica evidenciado de forma ainda mais clara pela irrelevância dos depoimentos dos "populares", destinados a cumprir um papel meramente ilustrativo, quando não folclórico, sem que se espere que produzam qualquer colaboração pertinente ao debate que se trava entre os atores políticos legítimos.

Existe uma correspondência entre uma compreensão restrita da política, a concentração do noticiário em personagens com perfil específico e a naturalização da hierarquia entre os temas e as experiências que constituem a agenda política e a agenda midiática. Vozes diversas (e dissonantes) poderiam impor à cobertura outras temáticas e mesmo forçar uma avaliação da hierarquia "natural" entre os temas no noticiário político ou entre os temas políticos e aqueles aos quais não se atribui essa rubrica. A especialização e a concentração em atores e temas legitimados pela configuração atual da política - e da política nos noticiários - têm, como um de seus aspectos, a confirmação da distância entre os poucos atores e os muitos espectadores.

O público consumidor de informação se encontra em posição similar à dos "populares", mesmo no caso das revistas, cujos leitores possuem um perfil bem mais elitizado do que os espectadores dos telejornais. Não se espera que esse público seja capaz de oferecer uma contribuição válida ao debate - as cartas dos leitores ocupam um espaço ilustrativo e anedótico similar aos depoimentos de transeuntes colhidos nas enquetes.

Não se espera nem mesmo que os consumidores de informação sejam capazes de entender o jogo político. Seja porque os políticos, com frequência, utilizam uma forma de expressão diferenciada, que marca sua distinção, seja porque suas palavras e ações só guardam pleno sentido no contexto de uma teia de relações que escapa aos profanos, a in- 
termediação dos jornalistas se torna fundamental para explicar ao público o que está acontecendo. Isso reforça a sensação de afastamento.

A política, nas chamadas "democracias representativas", de fato se faz assim, com a exclusão permanente do titular nominal da soberania, o povo. Mas a mídia não se limita a refletir uma realidade que a cerca; ela desempenha uma função ativa na reprodução de práticas sociais. Portanto, os telejornais e revistas semanais brasileiros não só descrevem uma situação de fato (o monopólio da atividade política pelos profissionais), eles a naturalizam diante de seu público e contribuem para sua perpetuação.

(Recebido para publicação em novembro de 2009)

(Versão definitiva em setembro de 2010) 


\section{NOTAS}

1. A resenha mais completa dos estudos sobre mídia e política no Brasil ainda é a de Rubim e Azevedo (1998). Uma década depois, o quadro parece basicamente inalterado.

2. Para uma discussão mais aprofundada da moldura teórica da pesquisa, ver Miguel e Biroli $(2009 ; 2010)$.

3. As gravações dos telejornais foram disponibilizadas pela ANDI (Agência de Notícias dos Direitos da Infância), cuja colaboração, em especial na pessoa de Railssa Alencar, agradecemos. O acompanhamento do noticiário envolveu uma grande equipe de estudantes da Universidade de Brasília (UnB). Somos gratos, em especial, às então mestrandas Helena Máximo e Janine Mello, que colaboraram com a coordenação da coleta de dados, e aos então graduandos Andrea Azevedo Pinho, Carla Beatriz de Paulo, Carla Bianca Caldas, Cleiton Euzébio de Oliveira, Fernanda Feitosa, Isadora Cruxên, Janaína Moreira Figueira, Luiz Augusto Campos, Mariana Silva Abreu, Natália Vieira, Nathália Mattos e Paula Pompeu Fiúza Lima. As bases de dados foram uniformizadas e corrigidas por Carlos Machado, Danusa Marques e Filipe Recch.

4. Por economia de linguagem, utilizamos o termo "matéria" para indicar todo material não publicitário das revistas e dos telejornais, incluindo reportagens, entrevistas, editoriais, artigos, colunas, críticas etc.

5. Longe de ser uma peculiaridade da cobertura eleitoral de 1998, o foco nas variedades marcou o período em que Evandro Castro de Andrade dirigiu a Central Globo de Jornalismo (1995 a 2001).

6. É frequente, por exemplo, que deputados e senadores atribuam à imprensa a culpa pela baixa confiança da opinião pública no Poder Legislativo. Agradecemos a Pedro Noleto por nos ter repassado a transcrição de depoimentos colhidos de uma amostra de congressistas.

7. A candidata Ana Maria Rangel (que obteve $0,13 \%$ dos votos válidos), no entanto, foi personagem de apenas oito matérias.

8. Usamos o termo "entrevistado" por comodidade, mas, a rigor, pode se tratar também de um trecho de uma declaração pública, de um discurso no plenário, de uma gravação clandestina etc.

9. A única exceção é a categoria "previsão do tempo", em que a presença de alguma personagem é absolutamente excepcional e que contou com nove mulheres e sete homens.

10. A presença dos negros foi quantificada pela identificação fenotípica da cor das personagens do noticiário dos telejornais, com base nos critérios correntes de atribuição de raça/cor no Brasil. Tal identificação foi feita pelos estudantes que participaram desta pesquisa. Personagens apenas citadas, sem imagem, não foram classificadas. $\mathrm{O}$ método é falho e foi utilizado como aproximação possível, na ausência de outros recursos. 


\section{REFERÊNCIAS BIBLIOGRÁFICAS}

ALDÉ, Alessandra. (2004), A Construção da Política: Democracia, Cidadania e Meios de Comunicação de Massa. Rio de Janeiro, Editora FGV.

BOURDIEU, Pierre. (1979), La Distinction: Critique Sociale du Jugement. Paris, Minuit.

. (1986), “La Représentation Politique: Eléments pour une Théorie du Champ Politique". Actes de la Recherche en Sciences Sociales, no 64, pp. 5-19.

COOK, Timothy E. (2005) [1998], Governing with the News: The News Media as a Political Institution ( $2^{\mathrm{a}}$ ed.). Chicago, The University of Chicago Press.

DELILLO, Don. (1987) [1985], Ruído Branco. São Paulo, Companhia das Letras.

ETTEMA, James S. e GLASSER, Theodore L. (1998), Custodians of Conscience: Investigative Journalism and Public Virtue. New York, Columbia University Press.

FSB COMUNICAÇÕES. (2008), Deputados Federais, Mídia e Conjuntura Política. Relatório de pesquisa. Brasília, FSB Comunicações.

GOMES, Wilson. (2008), Mapeando a Audiosfera Política Brasileira: Os Soundbites Políticos no Jornal Nacional. Trabalho apresentado no XVII Encontro da Compós. São Paulo, 3-6 de junho.

INSTITUTO VERIFICADOR DE CIRCULAÇÃO. (2009), “Jornais Populares Ativam o Mercado". Disponível em http://www.ivc.org.br/clipping/JornalP\&M_02022009. htm. Acessado em novembro de 2009.

MIGUEL, Luis Felipe. (1999), "Mídia e Eleições: A Campanha de 1998 na Rede Globo". DADOS, vol. 42, no 2, pp. 253-276.

. (2002), "Os Meios de Comunicação e a Prática Política". Lua Nova, nos 55-56, pp. 155-184.

. (2003), “A Eleição Visível: A Rede Globo Descobre a Política em 2002". DADOS, vol. 46, no 2, pp. 289-310.

. (2004), “Discursos Cruzados: Telenoticiários, HPEG e a Construção da Agenda Eleitoral". Sociologias, no 11, pp. 238-258.

e BIROLI, Flávia. (2009), “Mídia e Representação Política Feminina: Hipóteses de Pesquisa". Opinião Pública, vol. 15, no 1, pp. 55-81.

. (2010), “A Produção da Imparcialidade: A Construção do Discurso Universal a partir da Perspectiva Jornalística". Revista Brasileira de Ciências Sociais, no 73, pp. 59-76.

ROHDE, David W. (1979), "Risk Bearing and Progressive Ambition: The Case of Members of the United States House of Representatives. American Journal of Political Science, vol. 23, no 1, pp. 1-26.

RUBIM, Antonio A. Canelas e AZEVEDO, Fernando Antonio. (1998), “Mídia e Política no Brasil". Lua Nova, no 43, pp. 189-216.

SCHLESINGER, Joseph. (1966), Ambition and Politics: Political Careers in the United States. Chicago, Rand McNally. 


\section{Luis Felipe Miguel e Flávia Biroli}

SCHUDSON, Michael. (1995), The Power of News. Cambridge, MA, Harvard University Press.

SOUSA, Jorge Pedro. (2002), A Utilização de Fontes Anônimas no Noticiário Político dos Diários Portugueses de Referência: Um Estudo Exploratório. Trabalho apresentado no XXV Congresso Brasileiro de Comunicação. Salvador, 1-5 de setembro.

TEZZA, Cristovão. (2004), O Fotógrafo. Rio de Janeiro, Rocco.

THOMPSON, John B. (2002) [2000]. O Escândalo Político: Poder e Visibilidade na Era da Mídia. Petrópolis, RJ, Vozes. 


\section{ABSTRACT \\ Visibility in the Media and Political Field in Brazil}

This article presents the results of a comprehensive study on representations of politics in the Brazilian mass media. The data show that the various news media take a common view towards politics, expressed as homogeneous news concentrated on political players with a specific profile: white males, either elected officials or political nominees. The media give visibility to the players belonging to the political field (in the narrow sense of the latter term) and to those who already have the resources to make themselves seen and heard. The media thus confirm the hierarchies and limits of politics, reproducing and perpetuating narrow interpretations of democracy.

Key word: media; journalism; democracy; representation; visibility

\section{RÉSUMÉ}

Visibilité dans les Médias et Champ Politique au Brésil

Dans cet article, on présente les résultats d'une vaste recherche au Brésil sur les représentations de la politique au sein des moyens de communication de masse brésiliens. Selon les données, les véhicules analysés ont des vues communes de la politique, qui se traduisent par des nouvelles de l'actualité homogènes et concentrées sur des personnages aux profils assez semblables: hommes, blancs, titulaires de postes politiques électifs ou de confiance. Le journalisme offre une visibilité aux acteurs qui composent le champ politique au sens strict et qui disposent déjà des moyens de se faire voir et entendre. Il entérine ainsi les hiérarchies et les limites de la politique, reproduisant et rendant naturelle une compréhension restreinte de saisir la démocratie.

Mots-clé: Média; journalisme; démocratie; représentation; visibilité 